\title{
Treatment of Landfill Leachate RO Concentrate by VMD
}

\author{
Xingxing Qi ${ }^{a}$, Chaojie Zhang ${ }^{*}$, , Ying Zhang ${ }^{\mathrm{c}}$ \\ State Key Laboratory of Pollution Control and Resource Reuse, College of Environmental Science and Engineering, Tongji \\ University, Shanghai 200092, PR China
}

\begin{abstract}
Reverse osmosis (RO) concentrate has been one of the concerned environmental pollution since the RO membrane is widely applied. RO concentrate has a dramatic impact on the useful life of landfill, surrounding soil and ground water. Thus, the RO concentrate is also urgent to be solved. In this research, we firstly explored the characteristics of vacuum membrane distillation (VMD) by monitoring the membrane flux after controlling for three variables: inflow temperature, inflow flux and vacuum degree downstream and found out the optimum operating conditions. Then we further tracked the running instances of the system by testing the membrane flux and the effluent $\mathrm{pH}$, conductivity, TOC and COD at two different temperature. As for the membrane fouling and wetting, a SEM/EDX analysis was conducted and an efficient solution was given. Finally, we found out that when the vacuum pressure is set at $0.08 \mathrm{Mpa}$, inflow flux is set at $200 \mathrm{~L} / \mathrm{h}$ and at $75^{\circ} \mathrm{C}$ or $80^{\circ} \mathrm{C}$, we can get a relatively ideal membrane flux. The deterioration of effluent quality and membrane fouling happened in the VMD experiment at $80^{\circ} \mathrm{C}$ faster than at $75^{\circ} \mathrm{C}$ and "soaking with alkali, acid and tap water + drying” process is available to function recovery.
\end{abstract}

Keywords-reverse osmosis concentrate; vacuum membrane distillation; membrane fouling

\section{INTRODUCTION}

Since the leachate discharge standards were improved in China after the publication of $<$ Standards for pollution control on the landfill site of municipal solid waste> (GB16889-2008) in 2008, RO membrane have been more widely applied. If most concerning matter using the RO membrane is the concentrate, which is with no biodegradability, high salinity and high COD have been released into the environment, its persistent organic and inorganic pollutants will cause the pollution of solids, surface water and ocean and its excessive total suspended solids (TSS) has a negative effect on activated sludge growth. However, there is no perfect treatment for the membrane concentrate so far.In our study, we chose an efficient technology--vacuum membrane distillation (VMD) as the solution for $\mathrm{RO}$ concentrate reduction and a multivariable-control experiment was conducted to investigate the characteristics of $\mathrm{RO}$ concentrate. To further verify our consequences, we adopted the RO membrane concentrate from Liming landfill in Shanghai as our experiment subject.

\section{MATERIALS AND METHODS}

\section{A. Materials}

The characteristics of the RO concentrate from Liming landfill are listed in Table I

TABLE I. CHARACTERISTICS OF THE RO CONCENTRATE QUALITY

\begin{tabular}{cc|cc}
\hline Index & Value & Index & Value \\
\hline $\mathrm{pH}$ & 7.23 & $\mathrm{Na}(\mathrm{mg} / \mathrm{L})$ & 3914 \\
\hline Conductivity $(\mu \mathrm{S} / \mathrm{cm})$ & 51400 & $\mathrm{Mg}(\mathrm{mg} / \mathrm{L})$ & 498 \\
\hline $\mathrm{BOD}_{5}(\mathrm{mg} / \mathrm{L})$ & 365 & $\mathrm{Al}(\mathrm{mg} / \mathrm{L})$ & 14.50 \\
\hline $\mathrm{COD}_{\mathrm{Cr}}(\mathrm{mg} / \mathrm{L})$ & 7450 & $\mathrm{Zn}(\mathrm{mg} / \mathrm{L})$ & 0.80 \\
\hline $\left.\mathrm{TOC}^{2} \mathrm{mg} / \mathrm{L}\right)$ & 1820 & $\mathrm{Fe}(\mathrm{mg} / \mathrm{L})$ & 2.89 \\
\hline $\mathrm{NH}_{3}-\mathrm{N}(\mathrm{mg} / \mathrm{L})$ & 1580 & $\mathrm{Mn}(\mathrm{mg} / \mathrm{L})$ & 1.17 \\
\hline $\mathrm{TN}(\mathrm{mg} / \mathrm{L})$ & 4575 & $\mathrm{Cu}(\mathrm{mg} / \mathrm{L})$ & 0.14 \\
\hline $\mathrm{TP}(\mathrm{mg} / \mathrm{L})$ & 23 & $\mathrm{As}(\mathrm{mg} / \mathrm{L})$ & 0.52 \\
\hline $\mathrm{Cl}^{-}(\mathrm{mg} / \mathrm{L})$ & 6430 & $\mathrm{Ni}(\mathrm{mg} / \mathrm{L})$ & 0.37 \\
\hline $\mathrm{NO}_{3}{ }^{-}(\mathrm{mg} / \mathrm{L})$ & 5620 & $\mathrm{Cr}(\mathrm{mg} / \mathrm{L})$ & 0.32 \\
\hline $\mathrm{NO}_{2}{ }^{-}(\mathrm{mg} / \mathrm{L})$ & 5388 & $\mathrm{Cd}(\mathrm{mg} / \mathrm{L})$ & Undetected \\
\hline $\mathrm{SO}_{4}{ }^{2-}(\mathrm{mg} / \mathrm{L})$ & 453 & $\mathrm{~Pb}(\mathrm{mg} / \mathrm{L})$ & 0.13 \\
\hline $\mathrm{K}(\mathrm{mg} / \mathrm{L})$ & 3783 & $\mathrm{Be}(\mathrm{mg} / \mathrm{L})$ & Undetected \\
\hline $\mathrm{Ca}(\mathrm{mg} / \mathrm{L})$ & 552 & $\mathrm{Ba}(\mathrm{mg} / \mathrm{L})$ & 0.18 \\
\hline
\end{tabular}

B. Equipment of VMD

The equipment our research adopted is shown in Fig.1.

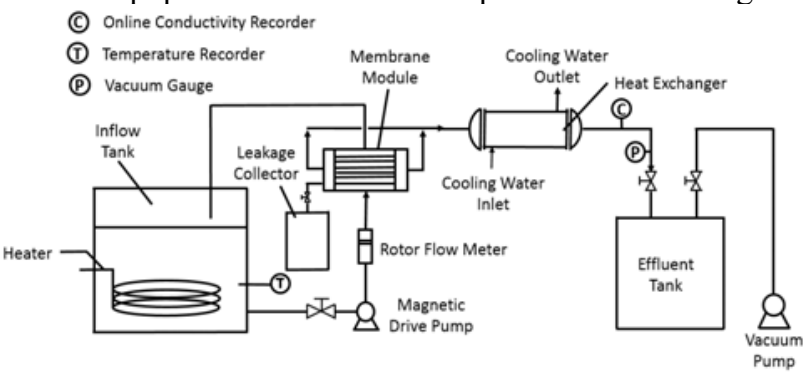

Figure 1. The VMD's Equipment 
1) Main Devices of VMD system

TABLE II. DEVICES’ DETAILED INFORMATIONS

\begin{tabular}{|c|c|c|}
\hline Device & Model & Materials\&Index \\
\hline Inflow Tank & Customized & $\begin{array}{c}\text { Polypropylene } \\
\text { (PP) V=25L }\end{array}$ \\
\hline Effluent Tank & Customized & PP V=6L \\
\hline Leakage Collector & Customized & PP V=5L \\
\hline Heater & Customized & Titanium P=1.5kW \\
\hline Heat Exchanger & Customized & $\begin{array}{c}\text { TitaniumEffective } \\
\text { Area }=0.5 \mathrm{~m}^{2}\end{array}$ \\
\hline Magnetic Drive Pump & MP-20R & $\begin{array}{c}\mathrm{Q}=22 \mathrm{~L} / \mathrm{min} \mathrm{H}=2 \mathrm{~m} \\
\mathrm{P}=20 \mathrm{~W}\end{array}$ \\
\hline Rotor Flow Meter & LZB-10 & $\mathrm{Q}: 25 \sim 250 \mathrm{~L} / \mathrm{h}$ \\
\hline $\begin{array}{c}\text { Circulating water } \\
\text { vacuum pump }\end{array}$ & SHB-B & $\begin{array}{c}\text { Max Vacuum } \\
\text { Degree }=0.1 \mathrm{Mpa}\end{array}$ \\
\hline $\begin{array}{c}\text { temperature } \\
\text { patrolinstrument }\end{array}$ & XSL16 $1 \mathrm{~A}-\mathrm{HV} 0$ & $\begin{array}{c}\text { Error }= \pm 0.2 \% \mathrm{~F} . \mathrm{S} \\
\text { Max value }= \\
1.0 \times 10^{4} \mu \mathrm{S} / \mathrm{cm}\end{array}$ \\
\hline $\begin{array}{c}\text { Online Conductivity } \\
\text { Recorder }\end{array}$ & CCT-5320 & $-0.1 \sim 0 \mathrm{Mpa}$ \\
\hline Vacuum Gauge & -- & \\
\hline
\end{tabular}

2) Membrane Modules

TABLE III. PARAmeters of MEMBrane Modules

\begin{tabular}{c|c|c|c|c}
\hline $\begin{array}{c}\text { Quantity of } \\
\text { Fiber }\end{array}$ & $\begin{array}{c}\text { Effective } \\
\text { Length }\end{array}$ & $\begin{array}{c}\text { Effective } \\
\text { Width }\end{array}$ & $\begin{array}{c}\text { Effective } \\
\text { Height }\end{array}$ & Effective Area \\
\hline 450 & $75 \mathrm{~mm}$ & $75 \mathrm{~mm}$ & $30 \mathrm{~mm}$ & $0.1 \mathrm{~m}^{2}$ \\
\hline Material & Width & $\begin{array}{c}\text { Inner } \\
\text { Diameter }\end{array}$ & $\begin{array}{c}\text { Outer } \\
\text { Diameter }\end{array}$ & $\begin{array}{c}\text { Average } \\
\text { Aperture }\end{array}$ \\
\hline $\mathrm{PP}$ & $220 \mu \mathrm{m}$ & $610 \mu \mathrm{m}$ & $1050 \mu \mathrm{m}$ & $0.2 \mu \mathrm{m}$ \\
\hline
\end{tabular}

The PPHFM are arranged parallel in the housing, with both ends stuck using epoxy resin sealant. The inlet and outlet of the feed liquid is perpendicular to the membrane, which is also called "cross-flow". Besides, when large amounts of liquid accumulate due to membrane wetting, it will run into the leakage collector.

\section{Methods}

1) Methods of Water Quality Monitoring

The main water quality indexes we monitored and their analysis methods are listed in Table IV

TABLE IV. ANALYSIS METHOD AND DEVICES

\begin{tabular}{c|c|c}
\hline Index & Method & Device \\
\hline $\mathrm{pH}$ & Glass Electrode Method & $\begin{array}{c}\text { HACH HQd } \\
\text { portable pH analyzer }\end{array}$ \\
\hline Conductivity & Electrode Method & $\begin{array}{c}\text { HACH HQd portable } \\
\text { conductivity analyzer }\end{array}$ \\
\hline $\mathrm{COD}_{\mathrm{Cr}}$ & $\begin{array}{c}\text { RACH DR-3900 } \\
\text { Rpectrophotometry Method } \\
\text { spectrophotometry } \\
\text { HACH DRB200 } \\
\text { elimination reactor }\end{array}$ \\
\hline BOD $_{5}$ & Pressure Transducer Method & HACH BODTrak \\
\hline TOC & $\begin{array}{c}\text { Non-dispersive Infrared } \\
\text { Absorption Method }\end{array}$ & $\begin{array}{c}\text { Shimadzu } \\
\text { TOC-L CPH/CPN }\end{array}$ \\
\hline
\end{tabular}

2) Methods of Test Items

To analyze the membrane fouling, SEM/EDX analysis was conducted to the hollow fiber membrane using the FEI Nano SEM 430 Ultrahigh resolution thermal field emission
SEM and X-ray energy dispersive spectrometer.

\section{RESUlTS AND DisCUSSION}

\section{A. Characteristics of VMD}

In this chapter, tap water were used to investigate how the operational factors influence the VMD process so as to understand the influence regularity of the operational index on membrane flux and prepare for the further study on the actual $\mathrm{RO}$ membrane concentrate. The temperature grades were designed as follows: $70^{\circ} \mathrm{C}, 75^{\circ} \mathrm{C}, 80^{\circ} \mathrm{C}, 85^{\circ} \mathrm{C}$, the flux grades were: $50 \mathrm{~L} / \mathrm{h}, 100 \mathrm{~L} / \mathrm{h}, 150 \mathrm{~L} / \mathrm{h}, 200 \mathrm{~L} / \mathrm{h}$, while the vacuum degree grades were: $0.08 \mathrm{MPa}, 0.07 \mathrm{MPa}, 0.06 \mathrm{MPa}$, $0.05 \mathrm{MPa}, 0.04 \mathrm{MPa}$

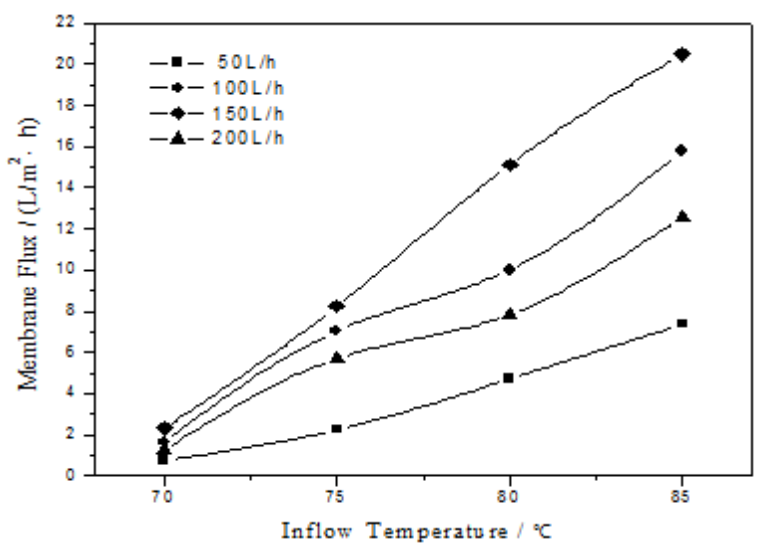

Figure 2. Influence of Inflow Temperature on Membrane Flux with Different Inflow Flux

1) The Influence of Inflow Temperature (Under the condition of 0.08MPa vacuum degree)

As shown in figure 2 above, the membrane flux had a correspondingly increased with the inflow temperature under definite system vacuum pressure and inflow flux. The rising saturated vapor pressure with temperature, causing the greater force membrane distillation driven by, finally came to the adding membrane flux. Concerned the heating as the main source of energy consumption, the cost was also taken in consideration when we decided the operational temperature in our experiments.

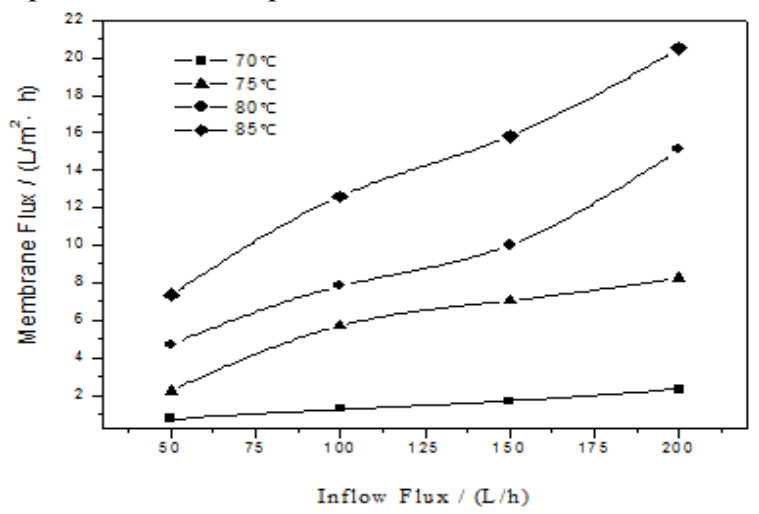

Figure 3. Influence of Inflow Flux on Membrane Flux with Different Inflow Temperature 
2) The Influence of Inflow Flux (Under the condition of $0.08 \mathrm{MPa}$ vacuum degree)

Figure 3 showed that the membrane flux increased when inflow flux increased and inflow temperature influenced growth ratio of membrane flux. With the inflow flux increased, the turbulence of fluids will rose, and then temperature polarization and concentration polarization weakened. Theoretically, latent heat of vaporization will grow when there is larger membrane flux, which makes the surface temperature of membrane lower, therefore the temperature polarization will be more significant even at a lower temperature. So the membrane flux depends more on turbulence than temperature.

There are some research reveals that the membrane flux will gradually tend to be steady with the growth of turbulence ${ }^{[1,2]}$. In fact, to increase the inflow flux has a less influence on temperature and concentration boundary layers when the turbulence reached a certain degree.

3) The Influence of Vacuum Degree Downstream(at $85{ }^{\circ} \mathrm{C}$ and $200 \mathrm{~L} / \mathrm{m}^{2} \bullet$ inflow flux)

The membrane flux held steady just under $3 \mathrm{~L} / \mathrm{m}^{2} \cdot \mathrm{h}$ when vacuum degree was below $0.06 \mathrm{Mpa}$ under definite temperature and inflow flux, and then the membrane flux made a linear increase along with the increment of vacuum pressure (see Graph 1.3). The transmembrane flux is proportional to vapor pressure difference (VPD) of water, expressed mathematically in formula 1 . When the temperature is constant in a VMD system, vacuum degree downstream become the determinant factor of VPD, explaining the linear increase of membrane flux with vacuum degree. However, when the vacuum degree is relatively low, its influence on mass transfer resistance is less than other factors, such as temperature difference, accounting for the flat part of the curve.

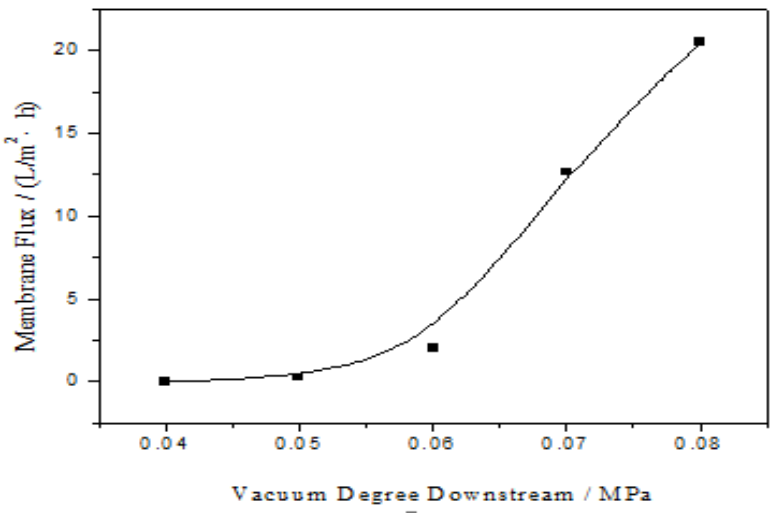

Figure 4. Influence of Vacuum Degree Downstream on Membrane Flux

$$
J=K_{m} \times \Delta p
$$

$J$ :Transmembrane flux, $K_{m}$ : Membrane Distillation Coefficient (MDC), $\triangle P:$ VPD of water ${ }^{[3]}$

Whereas, a higher vacuum degree is by no means better, when the vacuum degree is even higher than the LEP, the hydrophobic membrane channel get wetting and the percolation phenomena occur. $0.08 \mathrm{Mpa}$ is the highest vacuum degree we can stably implement and ensure of lower effluent conductivity so far, therefore, we chose $0.08 \mathrm{Mpa}$ as a fixed parameter to explore further about membrane distillation process.

\section{B. Study on the RO Concentrate treated by VMD}

According tothe prior study, the vacuum pressure is set at $0.08 \mathrm{Mpa}$, inflow flux is set at $200 \mathrm{~L} / \mathrm{h}$ and the temperature is $75^{\circ} \mathrm{C}$ or $80^{\circ} \mathrm{C}$ are relatively ideal conditions. Therefore, the following experiment was carried out under these conditions. Entering the carbonate balance principle of natural water ${ }^{[4]}$, the main speciation of carbonate was $\mathrm{HCO}_{3}{ }^{-}$and $\mathrm{H}_{2} \mathrm{CO}_{3} / \mathrm{CO}_{2}$ at $\mathrm{pH}$ below 6.3. In process of $\mathrm{VMD}$, $\mathrm{CO}_{2}$ dispersed when heating, making the $\mathrm{H}_{2} \mathrm{CO}_{3} / \mathrm{CO}_{2}$ convert to $\mathrm{HCO}_{3}{ }^{-} / \mathrm{CO}_{3}{ }^{2-}$. Using $2 \mathrm{~mol} \cdot \mathrm{L}^{-1}$ concentration of HClto adjust $\mathrm{pH}$ aimed to avoid $\mathrm{CaCO}_{3}$ sediment, the most common inorganic pollutant of membrane. The records of effluent conductivity was constantly proceeded using online conductivity recorder. While the membrane flux was measured by effluent volume every two hours and the $\mathrm{pH}$, $\mathrm{COD}_{\mathrm{Cr}}$ and TOC were recorded..

1) VMD Experiment under the Condition of $75^{\circ} \mathrm{C}$

From figure 5, the conductivity maintained in lower level (between 250 and $550 \mu \mathrm{S} / \mathrm{cm}$ ), compared to the original $51440 \mu \mathrm{S} / \mathrm{cm}$, so the desalination ratio reached up to $98.9 \% \sim 99.5 \%$ during the first 2 hours after running the system. But then,the leakage increased and showed similar conductivity to the inflow. It's very likely that the RO membrane might be perforated. After restarting the vacuum pump, conductivity moved up sharply to $2494 \mu \mathrm{S} / \mathrm{cm}$, $848 \mu \mathrm{S} / \mathrm{cm}$ and $1729 \mu \mathrm{S} / \mathrm{cm}$, and then recovered to the normal level (below $500 \mu \mathrm{S} / \mathrm{cm}$ ) in $0.5 \mathrm{~h}$. However the effluent quality grew significantly worse $10 \mathrm{~h}$ later, the conductivity even rose up beyond $9000 \mu \mathrm{S} / \mathrm{cm}$ and the average leakage reached to $1.5 \mathrm{~L} / \mathrm{h}$. This tendency was controlled after the system ran for $14 \mathrm{~h}$ and the effluent conductivity reduced to a stable level (below $300 \mu \mathrm{S} / \mathrm{cm}$ ).

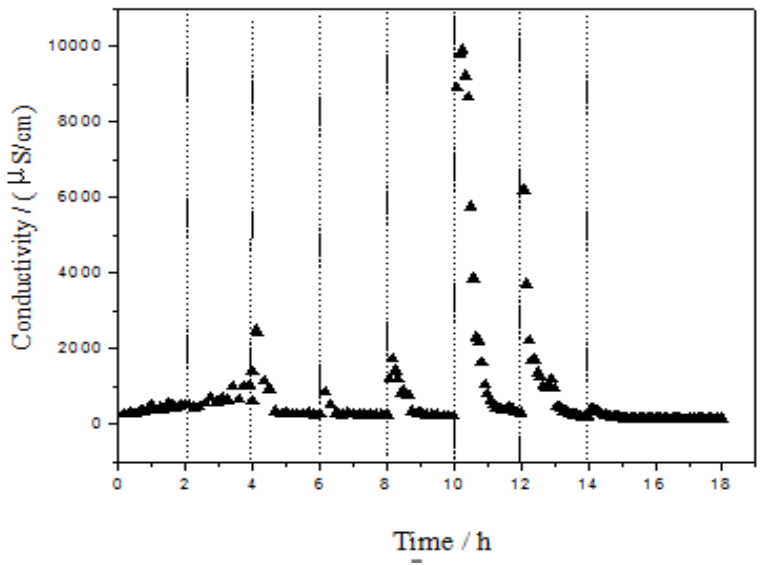

Figure 5. Real-time Recording of effluent Conductivity at temperature $75^{\circ} \mathrm{C}$

Figure 6 shows characteristics of effluent: $\mathrm{pH}, \mathrm{COD}$ and 
TOC every two hours (Sincethe effluent volume decreased, we changed the interval of sampling to $4 \mathrm{~h}$ for the last time). During the first $10 \mathrm{~h}, \mathrm{COD}$ retained its value between 120 and $180 \mathrm{mg} / \mathrm{L}$, and TOC was $25 \sim 30 \mathrm{mg} / \mathrm{L}$, which revealed that remove rate reached $97 \%$ above. Then the COD value dropped from $545 \mathrm{mg} / \mathrm{L}$ to below $200 \mathrm{mg} / \mathrm{L}$. The RO concentration contained numerous volatile acids. Their rapid volatilization during the first $6 \mathrm{~h}$ and dissolution in effluent made the effluent $\mathrm{pH}$ go up from 2.84 to 8.7 and finally reached a steady weakly alkaline or neutral state.
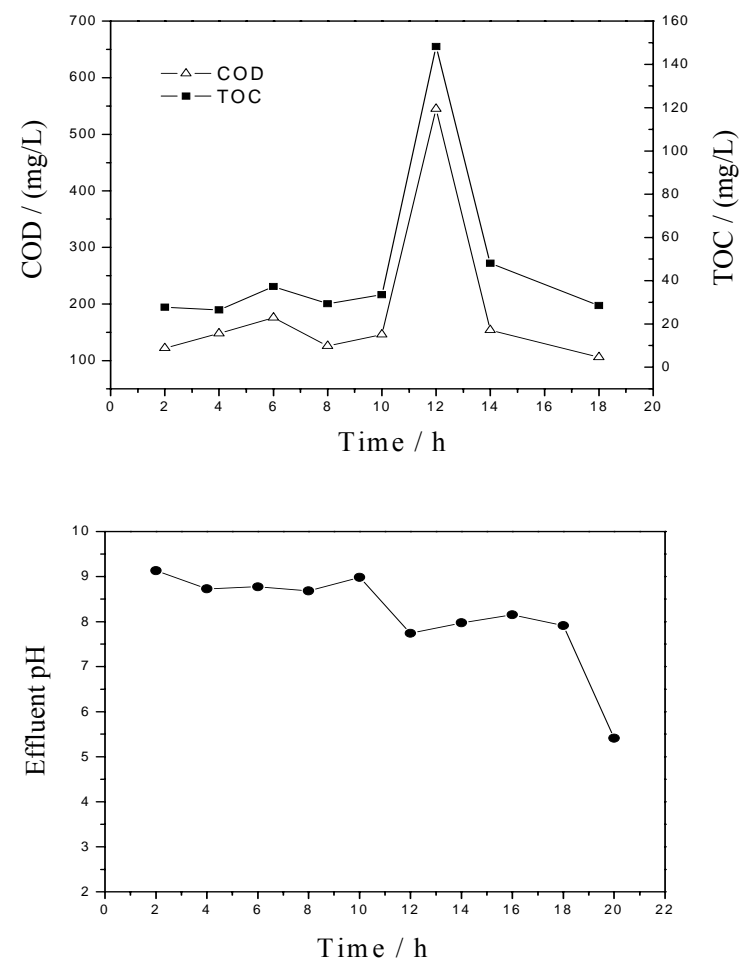

Figure 6. Effluent Characteristics of $\mathrm{pH}, \mathrm{COD}$ and TOC

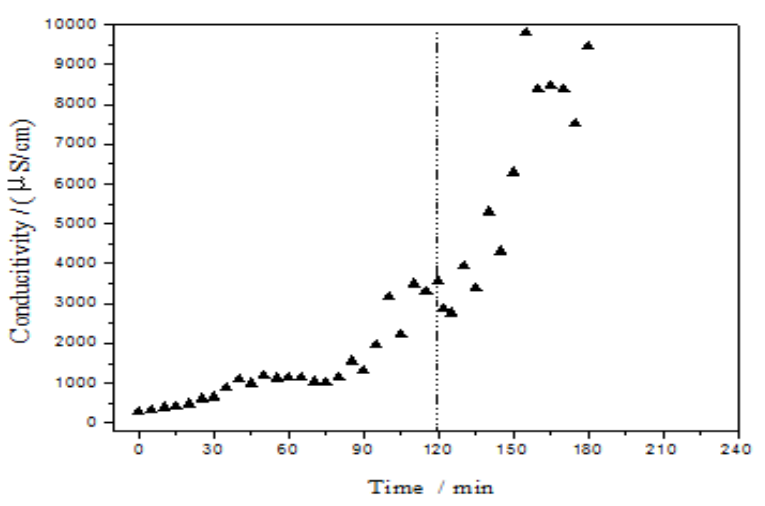

Figure 7. Real-time Recording of effluent Conductivity at temperature $80^{\circ} \mathrm{C}$

\section{2) VMD Experiment under the Condition of $80{ }^{\circ} \mathrm{C}$}

Only during the first $90 \mathrm{~min}$, the effluent conductivity kept its value below $1000 \mu \mathrm{S} / \mathrm{cm}$, then effluent quality worsened and its conductivity rose beyond the upper limit of online conductivity recorder and serious leakage happened. The conductivity, COD and TOC increased dramatically in 2 hours. The membrane pollution and concentration polarization led to the $30 \%$ drop in membrane flux compared with the tap water experiment under the same conditions (see Table V)

TABLE V. CHARACTERISTICS OF EFFLUENT SAMPLE

\begin{tabular}{cccccc}
\hline Sample Time & $\begin{array}{c}\text { Membrane } \\
\text { flux } \\
\left(\mathrm{L} / \mathrm{m}^{2} \bullet \mathrm{h}\right)\end{array}$ & $\begin{array}{c}\text { conductivity } \\
(\mu \mathrm{S} / \mathrm{cm})\end{array}$ & $\begin{array}{c}\text { COD } \\
(\mathrm{mg} / \mathrm{L})\end{array}$ & $\begin{array}{c}\text { TOC } \\
(\mathrm{mg} / \mathrm{L})\end{array}$ & $\mathrm{pH}$ \\
\hline $2 \mathrm{~h}$ & 10.5 & 1574 & 272 & 63 & 3.47 \\
$4 \mathrm{~h}$ & 10.75 & 9090 & 1172 & 363 & 5.01 \\
\hline
\end{tabular}

The membrane fouling, wetting and deterioration happened in shorter time. Firstly, the rising temperature made the membrane flux increase, and more serious concentration polarization accelerated the sediment of organic and inorganic pollutants ${ }^{[5]}$. Secondly, the colloids that were not removed by microfiltration were to blame for the membrane contamination. Big condensates combined by colloids deposited on the surface of membrane and higher temperature accelerated this process ${ }^{[6]}$. Thirdly, the temperature-sensitive organics might volatilized when the temperature rose and then when it got through the membrane channels, the organics condensed because of heat exchange, which weakened the hydrophobic and speeded up the wetting.

\section{Membrane Fouling Analysis}

1) Principle Components Analysis of Fouled Membrane

The SEM analysis revealed that the external surface of polluted membrane was covered by numerous granular and massive sediments while the internal was covered by plentiful flaky sediments. Table VI showed that the main elements on the external surface of polluted membrane were element $\mathrm{C}, \mathrm{O}, \mathrm{Ca}$, and $\mathrm{Na}, \mathrm{Cl}, \mathrm{Fe}, \mathrm{Mg}, \mathrm{Si}$ were detected. The content of oxygen increased due to the oxy-organics and inorganic salts. Since sulfur wasn't detected, the $\mathrm{CaSO}_{4}$ was ruled out from the possible staples and the $\mathrm{CaCO}_{3}$ was also excluded because of hydrolysis pretreatment. The RO concentrate was rich in humic acid (HA) and fulvic acid (FA) ${ }^{[7]}$, whose molecular chains contained carboxyl, phenolic hydroxyl groups and other oxygenic groups ${ }^{[8]}$. This made it possible for HA to ion exchange or chelate, so the carbon chains of HA winded. The increase of hydrophobic and winded carbon chains made the HA adsorption much easier. Therefore, it's well ground that gelatinous sediments chelated by HA and calcium ions. 
TABLE VI. EDXQUANTITATIVE ANALYSIS OF INTERNAL AND EXTERNAL SURFACE OF POLLUTED MEMBRANE

\begin{tabular}{|c|c|c|c|c|c|c|c|c|c|}
\hline \multirow{2}{*}{ Items } & \multicolumn{5}{|c|}{ External Surface } & \multicolumn{4}{|c|}{ Internal Surface } \\
\hline & 1 & 2 & 3 & 4 & 5 & 1 & 2 & 3 & 4 \\
\hline $\begin{array}{c}\mathrm{C}(\mathrm{w} \% \\
)\end{array}$ & $\begin{array}{l}17 . \\
49\end{array}$ & $\begin{array}{l}18 . \\
62\end{array}$ & -- & $\begin{array}{c}20 . \\
06\end{array}$ & $\begin{array}{l}18 . \\
59\end{array}$ & $\begin{array}{l}73 . \\
61\end{array}$ & $\begin{array}{l}79 . \\
88\end{array}$ & $\begin{array}{l}97 . \\
74\end{array}$ & $\begin{array}{l}73 . \\
71\end{array}$ \\
\hline $\begin{array}{c}\mathrm{O}(\mathrm{w} \% \\
)\end{array}$ & $\begin{array}{l}47 . \\
13\end{array}$ & $\begin{array}{l}54 . \\
48\end{array}$ & $\begin{array}{l}60 . \\
72\end{array}$ & $\begin{array}{l}40 . \\
77\end{array}$ & $\begin{array}{l}53 . \\
43\end{array}$ & $\begin{array}{l}26 . \\
39 \\
\end{array}$ & $\begin{array}{l}20 . \\
12\end{array}$ & $\begin{array}{c}2.2 \\
6\end{array}$ & $\begin{array}{l}26 . \\
29\end{array}$ \\
\hline $\begin{array}{c}\mathrm{Na}(\mathrm{w} \\
\%)\end{array}$ & -- & -- & -- & $\begin{array}{l}11 . \\
29\end{array}$ & -- & -- & -- & -- & -- \\
\hline $\begin{array}{c}\mathrm{Mg}(\mathrm{w} \\
\%)\end{array}$ & -- & $\begin{array}{c}1.2 \\
3\end{array}$ & -- & -- & -- & -- & -- & -- & -- \\
\hline $\begin{array}{c}\mathrm{Ca}(\mathrm{w} \\
\%)\end{array}$ & -- & $\begin{array}{c}25 . \\
48\end{array}$ & $\begin{array}{l}39 . \\
28\end{array}$ & $\begin{array}{c}4.8 \\
2 \\
\end{array}$ & $\begin{array}{l}27 . \\
97\end{array}$ & -- & -- & -- & -- \\
\hline $\begin{array}{c}\mathrm{Fe}(\mathrm{w} \\
\%)\end{array}$ & -- & -- & -- & $\begin{array}{l}11 . \\
04\end{array}$ & -- & -- & -- & -- & -- \\
\hline $\begin{array}{c}\mathrm{Si}(\mathrm{w} \% \\
)\end{array}$ & -- & -- & -- & $\begin{array}{c}2.3 \\
6 \\
\end{array}$ & -- & -- & -- & -- & -- \\
\hline $\begin{array}{c}\mathrm{Cl}(\mathrm{w} \\
\%)\end{array}$ & -- & -- & -- & $\begin{array}{c}9.6 \\
5\end{array}$ & -- & -- & -- & -- & -- \\
\hline
\end{tabular}

2) The Cleaning and Regeneration of Membrane

We adopted " $20 \mathrm{~min} \quad 0.05 \mathrm{~mol} \bullet \mathrm{L}^{-1} \mathrm{NaOH}+20 \mathrm{~min}$ $0.05 \mathrm{~mol} \cdot \mathrm{L}^{-1} \mathrm{HCl}+30 \mathrm{~min}$ tap water" process toclean the membrane. Its conductivity and membrane flux at $85^{\circ} \mathrm{C}$ turned out to be $40 \mu \mathrm{S} / \mathrm{cm}, 17.2 \mathrm{~L} / \mathrm{m}^{2} \bullet \mathrm{h}$ after $(98 \mu \mathrm{S} / \mathrm{cm}, 15.6$ $\mathrm{L} / \mathrm{m}^{2} \bullet \mathrm{h}$ before), which meant using acid and alkali didn't help. Then we used " $0.1 \mathrm{~mol} \bullet \mathrm{L}^{-1} \mathrm{NaOH}$ soaking for $5 \mathrm{~h}$, $0.1 \mathrm{~mol} \bullet \mathrm{L}^{-1} \mathrm{HCl}$ soaking for $5 \mathrm{~h}$, tap water soaking for $5 \mathrm{~h}$, drier at temperature $60{ }^{\circ} \mathrm{C}$ process and repeated. The average conductivity declined to $25 \mu \mathrm{S} / \mathrm{cm}$ while the flux was $18.5 \mathrm{~L} / \mathrm{m}^{2} \bullet \mathrm{h}$. No leakage showed it was available for function recovery.

\section{CONCLUSIONS}

Under current conditions, higher inflow temperature, greater vacuum pressure and larger flux will increase the membrane flux.In the VMD experiment at $75^{\circ} \mathrm{C}$, the wetting and leakage occurred in 4 hours and got worse over time, led to deterioration of effluent quality and decline of effluent flux. In the VMD experiment at $80{ }^{\circ} \mathrm{C}$, the membrane fouling and wetting worsened and the deterioration happened within 4 hours. The membrane fouling and wetting were attribute to organic and inorganic sediment. The LEP decreased due to highly concentrated organic matters, so the wetting accerlarated. The SEM/EDX analysis indicated that the main contaminants on the external surface are gelatinous sediments while internal contaminants are oxy-organics."Soaking with acid and alkali + drying" process is the most effective for function recovry

\section{REFERENCES}

11 Tang Na \& Ma Jing-huan. Seawater Desalination by VMD with IPP Flat Sheet Microfiltration Membranes Module. Technology of water treatment. 06, pp.5-7, 2006.

[2] Wang Juan, Yang Zai-fu. Application of Fenton Oxidation Technology in Wastewater. Environmental Science and technology. 11, pp.104-108, 2011.

[3] Dai Shu-gui. Environmental Chemistry. Beijing: Higher Education Press, pp.518, 2006.

[4] Wu Cheng-qiang, Chen Shi-dong, Zhao Bao-dong, et al. Coagulation mechanism of the Fenton's oxidation process treating the landfill leachate.Journal of Zhejiang University of Technology. 05, pp. 484-487, 2012.

[5] Ma Fang-wei, Wan Jia-feng, Li Hong, et al. Study on Membrane Fouling and Membrane Resistances in Vacuum Membrane Distillation Process. Technology of water treatment. 05, pp. 54-57, 2010 .

[6] Song Sha-sha. Membrane Distillation-Based Industrial Organic Wastewater Treatment and Membrane Fouling Study. Tianjin University, 2009.

[7] Zhang Q, Tian B, Zhang X, et al. Investigation on characteristics of leachate and concentrated leachate in three landfill leachate treatment plants. Waste Management. 11, pp. 2277-2286, 2013.

[8] Gao Hai-rui, Wang Jun, Wang Yong-hong, et al.Effects of Natural Organic Matters and Inorganic Salts on Membrane Distillation Process. China water and wastewater. 21, pp. 33-36,200 